\title{
DIVINE AND HUMAN ACTION IN EURIPIDES’ HELEN
}

\author{
Eleni Kornarou \\ Hellenic Open University \\ egkornarou@hotmail.com
}

\begin{abstract}
This article discusses the interplay of divine and human action in Euripides' Helen. Due to their limited understanding and the deception of the gods, mortals are often led to miscalculations and errors. Yet this does not mean that they cannot act as free agents. The plot of the play indicates that within the limits of their humanity, men can determine their fortunes by their own decisions and attitude to life, despite the fact that the motives and the nature of the gods remain ambiguous.
\end{abstract}

KEYWORDS: Euripides' Helen, divine - human action, illusion - reality.

\section{ACCIÓN DIVINA Y HUMANA EN LA HELENA DE EURÍPIDES}

\section{RESUMEN}

Este artículo discute la interacción humana y divina en la Helena de Eurípides. Debido a su limitada comprensión y al engaño de los dioses, los mortales a menudo son llevados a conclusiones erróneas y a errores de juicio. Aun así, esto no significa que no puedan actuar con libertad. La trama de la obra indica que dentro de los límites de su humanidad, el hombre puede determinar su suerte por sus propias decisiones y actitud ante la vida, a pesar del hecho de que los motivos y la naturaleza de los dioses sigan siendo ambiguos.

PALABRAS ClaVE: Helena de Eurípides, acción divina - humana, ilusión - realidad.

Euripides' Helen must have made a striking impression on its audience in 412 B.C., as is made evident in its extensive parody in Aristophanes' Thesmophoria-

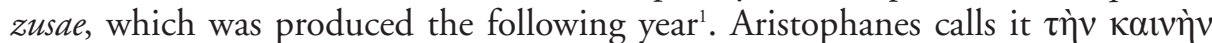
'E $\lambda \varepsilon^{\prime} v \eta v$ (Th. 850), which is usually considered to be an allusion to the version of the myth that Euripides dramatizes, according to which a phantom of Helen created by Hera went to Troy, while the true Helen was transferred by Hermes to Egypt, where she remained during the Trojan war until Menelaus' arrival ${ }^{2}$. Although this variant of the myth was not completely new ${ }^{3}$, it must have struck the Athenian audience as an unusual one.

There are clues in several parts of the play that there is a divine plan of larger scope behind what happens. In the prologue Helen mentions that Zeus' purpose 
in causing the Trojan war was «to lighten earth's burden from people» and «to make Achilles famous" (36-41). She also refers to Hermes' promise about her return to Sparta together with Menelaus (56-58) while later she reminds Theonoe that it is the will of the gods that she should be given back to her husband (914-917). Finally in the exodos of the play the Dioscuri declare that everything has been ordained by the gods (1646-1655, 1660-1661, 1669, 1676-1677), restoring Helen's ill-fame (1686-1687) and announcing the divine honours she will receive after death (1666$1669)^{4}$ as well as Menelaus' happy future in the Isles of the Blessed (1676-1677). After all the suffering the couple have endured in the hands of the gods, they will be rewarded after death, and so harmony will be finally restored.

However, besides the grand divine plan the jealousies and whims of the gods are given striking prominences. Helen's removal to Egypt appears in the prologue as a part of Zeus' plan to protect her (44-48), but later it is described as an act of a capricious goddess who sent Hermes to snatch her away $(241-249)^{6}$. Zeus himself is presented on the one hand as a higher divinity who cares for the Earth and on the other as an immoral god with bestial instincts who takes the form of a swan to seduce Leda ${ }^{7}$ $\left(17-21^{8}, 214-216\right)^{9}$. The paradoxical situation itself of a phantom Helen and a real Helen, which causes confusion between appearance and reality, is the result of Hera's fraud ${ }^{10}$ : angry for her defeat in the beauty contest, the goddess fashioned a phantom from air (31-35) ${ }^{11}$, which Paris got, thinking that it was the real Helen. Moreover Hera's willingness to help Menelaus and Helen to return to Sparta and Aphrodite's

\footnotetext{
' For the parody of Helen in Thesmophoriazusae, see Rau, 1967: 53-65; Kannicht, 1969: I. 79-82; Nieddu, 2004; Burian, 2007: 41-43.

${ }^{2}$ Griffith, 1953: 36; Burian, 2007: 1. Euripides also alludes to this story in his earlier Electra 1280-1283.

${ }^{3}$ For Stesichorus' and Herodotus' accounts of the innocent Helen who never went to Troy, see Dale, 1967: XVII-XXIV; Kannicht, 1969: I. 26-48; Burian, 2007: 4-9.

${ }^{4}$ Helen's final divinity is suitable to the myth of her parentage from Zeus (cf. Podlecki, 1970: 406-407).

${ }^{5}$ For the ambiguity of the gods' motives, see Conacher, 1967: 301-302; Dunn, 1996: 143-147.

${ }^{6}$ For the antithesis between the two gods, representing the contrast between cosmic order and cosmic chaos, see Segal, 1971: 565.

${ }^{7}$ Like all divinities in Euripidean tragedy, Zeus in Helen combines advanced and primitive elements (cf. Wassermann, 1940: 590).

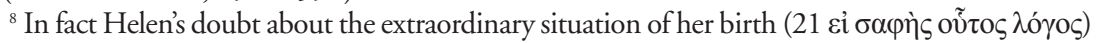
«underscores the impossibilities upon which the play is based» (Hartigan, 1981: 24). Such sceptical remarks are usual in Euripidean plays (e.g. HF 1341-1346, IT 380-391).

${ }^{9}$ The motif of a male divinity using a female mortal to satisfy his lust raises questions about the morality of the gods and the world in which mortals have to live subject to the gods' passions (Wassermann, 1940: 588; Hartigan, 1981: 24). The 'rape-theme' is also reiterated in the picture of Pan pursuing the Nymphs and Naiads (185-190) as well as in the case of Helen who was carried away by Hermes as she was plucking flowers (244-249; cf. Apollo's rape of Creousa in Ion 887-896 against a similar quasi-pastoral background).

${ }^{10}$ Cf. 586, 610, 1135-1136.

${ }^{11}$ Segal (1971: 564-565) points out that the language of the above passage, with the repetition of words of air and wind, underlines the unreality of the eidolon.
} 
wish to destroy them (880-886) are also prompted by personal motives as Hera wants to disclose to everybody Paris' 'false' marriage with Helen, whereas Aphrodite wishes to conceal the truth ${ }^{12}$.

The antithesis between illusion and reality, which is frequently expressed by the contrast between övo $\mu \alpha$ and $\pi \rho \tilde{\alpha} \gamma \mu \alpha$ (or $\sigma \tilde{\omega} \mu \alpha)^{13}$, is the most prominent motif of the play ${ }^{14}$, and raises the question about the true nature of reality, a question which lies at the heart of the sophistic debates of the late $5^{\text {th }}$ cent. $\mathrm{BC}^{15}$. The existence itself of two Helens, a mere image and a real one, stresses the contrast between appearance and reality, and is also the starting point of a deliberate doubling of elements in the $\operatorname{plot}^{16}$. No wonder that all the characters of the play, with the exception of the omniscient prophetess Theonoe, mistake the truth for illusion and vice versa $a^{17}$.

So in his encounter with Helen Teucer ${ }^{18}$ ironically attributes to the real Helen

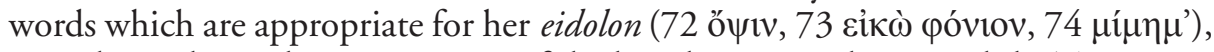
considering her to be an imitation of the hated woman who caused the Trojan war and getting ready to kill her for her likeness to Helen (75-77). Like all the Greeks and the Trojans, he is a victim of the deception contrived by Hera, and although Helen

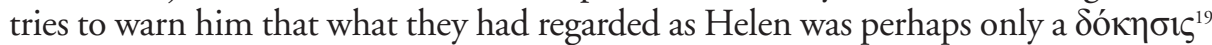
$(119,121)$, Teucer is unable to realize the truth. Finally on departing he pronounces a curse on the Helen of Troy and a blessing on the woman in front of him (162-163). The irony is obvious throughout the scene, and although its effect may be comic, as it has been argued ${ }^{20}$, it serves a serious purpose, to show how people can be deceived by the gods so as to mistake reality for its image and the opposite.

${ }^{12}$ As Zuntz (1960: 217) comments, the two goddesses «reveal themselves as mythological embodiments of the incalculable and unmanageable forces which preside over all man's strivings».

${ }^{13}$ For this antithesis, which is constantly repeated throughout the play (e.g. 42-43, 66-67, $588,601,1100)$ and occasionally also occurs in other Euripidean plays dated closely before or after Helen (e.g. IT 504, Or. 390), see Solmsen, 1934; Kannicht, 1969: I. 57-60; Wright, 2005: 307-316.

${ }^{14}$ Cf. Pippin, 1960: 151; Zuntz, 1960: 223; Segal, 1971: 559; Boedeker, 2017: 246. Although the conflict between appearance and reality is also exploited in other Euripidean plays of the same period such as Andromeda, IT and Ion (cf. Forehand, 1979: 174, 185; Wright, 2005: 278-337), Helen is considered to be the most extreme exploitation of it (Lattimore, 1958: 122-123; Pippin, 1960: 154; Hartigan, 1981: 23 n. 1).

${ }_{15}^{15}$ See Kannicht, 1969: I. 57-60; Segal, 1971: 560-561; Conacher, 1998: 70-83.

${ }^{16}$ There are two 'prologues', two Greek warriors shipwrecked in Egypt (68ff, 386ff), two confused encounters with Helen (72ff, 546ff), two tales about Dioscuri's fate (137-142), the tale of Helen's double parentage (17-19, 470-472) etc. (cf. Zuntz, 1960: 223; Segal, 1971: 562; Wright, 2005: 328).

${ }^{17}$ Pippin, 1960: 152; Zuntz, 1960: 222.

${ }^{18}$ Although Teucer's arrival serves various purposes (i.e. to inform Helen of the outcome of the Trojan war and the fate of Menelaus and her family as well as to reveal the hatred of the Greeks towards her and thus to magnify her feeling of guilt), its main purpose is to emphasize the antithesis between reality and illusion (Segal, 1971: 563).

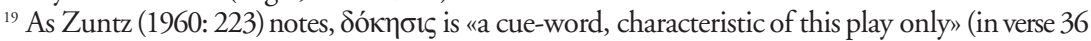
it is characterized as $\kappa \varepsilon v \eta \dot{v}$, which reveals the contrast between appearance and reality). Wright (2005:

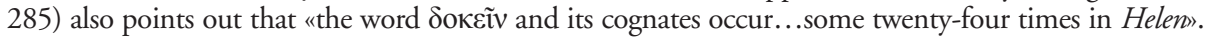

${ }^{20}$ Cf. Grube 1941: 336; Burnett, 1971: 77. 
After Teucer's departure Helen bursts into a passionate dirge about her misfortunes joined by the chorus in an amoibaic parodos which deepens her suffering. In her unhappiness she even forgets Hermes' promise which she herself had reported in the prologue about her eventual reunion with Menelaus (56-58). In fact, although

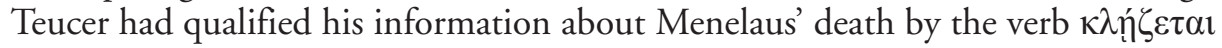
$(126,132)$, and despite the fact that the chorus express their doubt about the veraci-

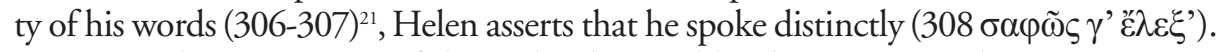

Helen is a victim of the gods who used her beauty to set the Trojan war in motion. She regards her beauty as a curse, a commonplace in Greek literature, and she refers repeatedly to the disaster it caused $(27,236-237,261,304-305)^{22}$. She also refers to two other heroines, Callisto and Merops' daughter, who suffered because of their beauty $(375-383)^{23}$, yet she distinguishes herself from them as her beauty proved disastrous for thousands of people (383-385). Although she speaks of her beauty as something separate from herself ${ }^{24}$, we cannot detach her from it, in the same way that we cannot detach her from the bitter story of Troy, even though in this version of the myth she is a faithful wife like Penelope waiting for her husband for seventeen years. She is innocent, yet she feels that she is guilty because her beauty caused the war, no matter that she never went to Troy ${ }^{25}$. She expresses her sympathy for the woes of both the Trojans and the Greeks (e.g. 39, 109, 196-197, 362-374), applying to herself the epithet $\pi 0 \lambda v \kappa \tau$ óvo (198) which she also uses to characterize Aphrodite (238) - the archetypes of disastrous beauty in the mortal and divine worlds respectively. In this way Euripides does not allow us to forget the guilt of the Homeric Helen, although he dramatizes the anti-Homeric version of the myth ${ }^{26}$. It is obvious that for Helen the worst of her misfortunes is that she is ill-famed undeservedly everywhere, and she repeatedly grieves for her aischyne (53-55, 250-252, 270, 927-928) ${ }^{27}$. Her ővo $\mu \alpha$, her $\kappa \lambda \varepsilon \dot{\delta} \delta$, which she sets against her private self, her $\sigma \tilde{\omega} \mu \alpha$, is «her social and public being which she must bear like an imposed necessity»"

${ }^{21}$ The opposition between word and actuality is recurrent in Helen (cf. also 1050, 1052).

${ }^{22}$ See Segal, 1971: 569; Whitman, 1974: 44. As Segal (1971: 571) points out, the theme of beauty as a curse has its parallel in the divine sphere as well, in the beauty contest among the three goddesses (23), so that both worlds seem to be subject to the same destructive forces. For a discussion of the significance of Helen's beauty in mythology, see Blondell, 2013: 27-52.

${ }^{23}$ The Sirens, winged female creatures, whom Helen invokes to accompany her lamentation in the parodos (167ff), also cause destruction via their beauty.

${ }^{24}$ In fact Aphrodite promised to grant Paris Helen's beauty, not herself (27-28), which he did receive in the form of the phantom contrived by Hera (Luschnig, 1972: 161).

${ }^{25}$ Nevertheless, as Luschnig (1972: 160) writes, «the consequences were the same as if she had gone».

${ }^{26}$ Segal, 1971: 577. Cf. also Whitman, 1974: 43: «Euripides has managed to give his Helen her full load of sensed guilt, while at the same time presenting her in the image of feminine perfection».

${ }^{27}$ Cf. Pippin, 1960: 153.

${ }^{28}$ Wolff, 1973: 79. 
Troy is the centre of Helen's dyskleia, as it is of Menelaus' kleos ${ }^{29}$ and Helen's lament over the woes of the war (362ff) is sharply contrasted with his boasting of his forces at Troy $(392 \mathrm{ff})^{30}$.

Like Teucer, Menelaus is subject to ambiguity and delusion. Confused by the old woman's statement about Helen and in trying to work out the truth, he considers the possibility of the existence of double names/places (497-499) in a comic scene with serious undertones revealing the tragic situation of mortals, who are at the mercy of the gods who deceive and misinform them. Similarly Menelaus' insistence on the kleos of his name (501-504) is certainly ironic since that glory rests on the pursuit of an empty image ${ }^{31}$.

In his encounter with Helen Menelaus refuses to believe what he sees and, like Teucer, he takes the real Helen for a phantom (569 $\varphi \alpha ́ \sigma \mu \alpha \tau$ '). Employing, like Teucer, vocabulary referring to sense-perception and knowledge, Menelaus expresses his belief that the mind perceives reality while the eye only its appearance $(575 \mathrm{ff})^{32}$, although in this case the opposite happens: his mind tells him a lie and his eye the truth. By contrast, Helen points to the eyes as the most reliable organs of perception $(580)^{33}$. Menelaus is ready to return to the phantom Helen, leaving behind him the real one, when the messenger's statement that the Helen they were guarding in the cave disappeared into the sky enables him to realize the truth. What this scene, and the play as a whole, indicates, is men's limited understanding and the view that true knowledge cannot be achieved by means of human perception and reason, but only through divine authority.

The confusion of identity and delusive appearance is repeated in the second half of the play, in the deception scene. Supported by the chorus, Helen deceives Theoclymenus ${ }^{34}$ by using Teucer's report about Menelaus' supposed death. As elsewhere

${ }^{29}$ Cf. Segal (1971: 577), who points out the different ways in which Helen and Menelaus use the words kleos, aischyne etc.

${ }^{30}$ Menelaus enters alone after the departure of Helen and the chorus. The tragic chorus rarely leaves the orchestra during the performance of the play and their departure now leaves the way open for a second prologue by Menelaus, which gives him startling prominence (Burnett, 1971: 80; Whitman, 1974: 45; Arnott, 1990: 10-11; Marshall, 2014: 30-31).

${ }^{31}$ Cf. Meltzer, 2006: 188-222. Menelaus has often received negative criticism from scholars: he is a miles gloriosus (Grube 1941: 339), «insincere as well as weak» (Blaiklock, 1952: 87), «somewhat limited intellectually» (Griffith, 1953: 37; see also Segal, 1971: 575 n. 65). Yet, although his boasting of his kleos (392-399, 501-504), his lament for the loss of his clothes (421-424) and his armies (453), and generally his weakness before the portress (441-445, 456-457) may provoke the audience's laughter, his situation is a quite serious one; he is a warrior who, shipwrecked in an alien land, finds himself in a really desperate situation, where his military experience cannot help him (Podlecki, 1970: 403).

${ }^{32}$ Pippin, 1960: 152.

${ }^{33}$ As Solmsen (1934: 121) points out, in this play Euripides shows, more than in any other, a special interest in questions of perception and cognition.

${ }^{34}$ Some scholars criticize the Greek couple for using religion to deceive their host; yet, as others argue, Theoclymenus is presented as a 'cruel despot' (Pippin, 1960: 157), 'immoral' and 'irreligious', who «is after all getting what he deserves» (Hanson, 1973: 12, 20). 
in the play, the contrast between word and reality is striking here: by his fictitious

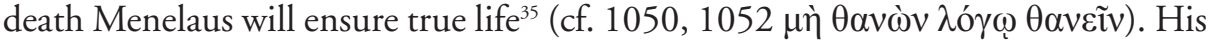
cenotaph becomes the counterpart to Helen's eidolon that dominated the first half of the play, and his real situation as a shipwrecked, ragged sailor (1079-1080, 1204) is used to deceive Theoclymenus, just as Helen's true self had deceived Teucer and Menelaus earlier. The will of the gods is that Helen should return to Sparta together with Menelaus (56-58), but the means of their salvation, after they have persuaded Theonoe to conceal the truth, lies entirely in themselves (1022). Their wits, especially Helen's, triumph ${ }^{36}$ as they exploit the customary funerary ritual to conduct the burial of the supposedly dead Menelaus while Theoclymenus, ignorant of their plans, helps the Greek couple and at the very moment he is deceived, he thinks that he has Helen within his grasp (1385-1386), as Paris did (35-36) ${ }^{37}$.

The arbitrary and deceptive ways of the gods is what prompts Menelaus' servant to indulge in a philosophical consideration of the nature of God (711ff), remaining on the stage, contrary to convention ${ }^{38}$, after he has fulfilled his dramatic purpose to report the disappearance of the phantom Helen. The discovery of the real Helen makes him realize that the Trojan war was fought in vain ${ }^{39}$ for an empty illusion and thus that man lives in an amoral universe where the gods' deceit is an undoubted fact and the success of his aims does not depend on his striving but on fortune and on the goodwill of the gods ${ }^{40}$. The chorus also share the same view (758-760), agreeing with the servant that men should leave aside divination which has proved ineffective ${ }^{41}$ and pray for the favour of the gods.

The second strophe of the first stasimon (1137-1150) picks up the cue given by the messenger and comments on the incomprehensibility of divinity and

\footnotetext{
${ }^{35}$ Segal, 1971: 564 .
}

${ }^{36}$ In Helen Euripides has elaborated on the motif of the prominent female guile exploited also in $I T$ (cf. Segal, 1971: 575, 579), two tragedies with barbaric setting where Greek men are found in danger.

${ }^{37}$ In Helen's concern for the supposedly dead Menelaus Theoclymenus sees the confirmation of a chaste wife for him (in fact, in the end he praises Helen for her outstanding virtue and most noble character: 1684-1687). For Theoclymenus as a somewhat 'comic' figure like Menelaus, see Segal, 1971: 583-584.

${ }^{38}$ Cf. Arnott, 1973: 62; Hamilton, 1978: 290.

${ }^{39}$ The repetition of the word $\mu \alpha \dot{\tau} \eta v(603,751,1220)$ underlines the futility of the war.

${ }^{40}$ Dale (1967: $117 \mathrm{n}$. on 744-60) argues that the messenger is not the appropriate person to comment on such serious matters. Yet, as Galeotti (1987: 31) points out, it is surely not accidental that Euripides employs a minor character to comment on the play's major issue; this choice as well

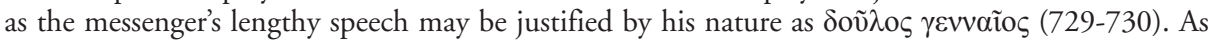
conventionally in Euripidean tragedy, nobility is related not to birth but to free mind (cf. $728 \mathrm{ff}$ ).

${ }^{41}$ The messenger's attack upon the seers (744ff), «as round and outspoken a denunciation of pseudo-prophecy as any in Euripides» (Griffith, 1953: 39), was probably prompted by the disastrous effect they had had concerning the Sicilian expedition (cf. Griffith, 1953: 39; Zuntz, 1960: 215; Dale, 1967: 118). 
the unpredictability of human affairs, following upon the previous two stanzas which elaborate on the mortal pain caused by Aphrodite and Hera. The nature of divinity is beyond the limits of human perception and there is no hope that man can ever find out what deity really is. Helen's suffering despite her divine ancestry illustrates the chorus' conclusion. As Zuntz (1960: 218) comments, while the obscurity of divinity is a commonplace in Greek literature, here "you are... aware of the greater, and indeed absolute radicalism which distinguishes this utterance in Euripides...from all others $\aleph^{42}$.

Zeus' plan caused death to thousands of people and Hera's fraud made the Trojan war fought for an eidolon, while the innocent Helen was ill-famed everywhere. The vanity of the war is stressed throughout the play $(603,707,751,1220)$ and so are the immense suffering and the countless deaths (52-53, 73-74, 109-110, 362-374, 691-693, 969-970 etc.). In the first strophic pair of the first stasimon (1107-1136) the chorus lament for the sufferings of the Trojans (strophe) and the Greeks (antistrophe), while the names of Aphrodite and Hera, whose हैpıs caused the war, are emphatically placed at the end of each stanza $(1121,1136)$. The bitter conclusion of all this is that the gods use mortals in order to achieve their purposes without being concerned for the confusion and suffering they cause.

The slaughter of the Egyptians at the end of the play is also necessary so that the divine plan of Menelaus' and Helen's restoration may be accomplished. Although some scholars have argued that this violent deed is not to be taken too seriously ${ }^{43}$, it is neither presented, I think, as simply «the blood of a good messenger speech $»^{44}$. Throughout the play Euripides tries to convince us that the $\sigma \tilde{\omega} \mu \alpha$, the reality, lies in Egypt and the övo $\mu \alpha$, the appearance, in Troy. However at the end of the play Helen prompts the Greeks to slaughter the Egyptians (1602-1604). She regains the traditional role of the Helen who causes death and disaster wherever she goes ${ }^{45}$. In a sense Egypt becomes the setting for a second 'Trojan war', on a smaller scale, but now Helen is on Menelaus' side ${ }^{46}$. Finally she is inseparable from the story of Troy ${ }^{47}$. Ending his play in this way Euripides leaves us in doubt about which of the two Helens and which of the two worlds, that of Troy or that of Egypt, is the real one. The question about the true nature of reality finally remains unresolved ${ }^{48}$. Yet, even if the eidolon of Helen is unreal, «the consequences of that unreality are quite real and disastrous», and "[t]he happy ending does not erase all the misery that

${ }^{42}$ Zuntz, 1960: 218.

${ }^{43}$ See Segal, 1971: 606 n. 122.

${ }^{44}$ Burnett, 1971: 97.

${ }^{45}$ Cf. Luschnig, 1972: 162: «At the end of the play, the two Helens seem to merge into one: men are still willing to die and kill for her beauty».

${ }^{46}$ Segal, 1971: 606; Luschnig, 1972: 162; Meltzer, 2006: 217.

${ }^{47}$ As Zuntz (1960: 224) comments, «the poet has embodied in it [the play] some significant touches which prevent the real Helen of Troy from being totally eclipsed, in the mind of the spectator, by her innocent double».

${ }^{48}$ Cf. Segal, 1971: 559. 
went before $»^{49}$. The vanity of the war and the suffering of mortals because of their deception by the gods is an undoubted fact.

The ode on the Great Mother (1301-1368), a much-debated passage regarding its interpretation and its relationship to the rest of the play ${ }^{50}$, provides another example of mortal pain caused by the passion of a goddess, and so it is related to the story dramatized in Helen. The nameless goddess mentioned in this stasimon is generally considered to be Demeter ${ }^{51}$ who, inconsolable at the loss of her daughter, destroys men by imposing barrenness on the earth, as Hera, angry with Paris' judgement, causes the suffering of the Greeks and the Trojans by contriving a cloud-image of Helen. In both cases Zeus finally restores harmony, but it is only after a long period of mortal suffering ${ }^{52}$.

Although, as noted above, the war is presented as the result of the whims of the gods, mortal responsibility is not excluded ${ }^{53}$. In the final stanza of the first stasimon Euripides calls ö $\varphi \rho 0 v \varepsilon \varsigma$ (1151) those who seek to settle their differences by war, underlining their folly with the word $\dot{\alpha} \mu \alpha \theta \tilde{\omega} \varsigma$ (1153). Fighting always leads to destruction while sound reasoning can avoid it and settle differences peacefully (1151-1164) $)^{54}$. The poet of course addresses his contemporaries whose greed led them to the Sicilian expedition and disaster ${ }^{55}$. Yet the reference in the same stasimon to the

${ }^{49}$ Luschnig, 1972: 158.

${ }^{50}$ Although several scholars have regarded this ode as dramatically irrelevant (cf. Segal, 1971: 595 n. 103; Hanson, 1973: 20 n. 30; Whitman, 1974: 65, who points out that it is "generally considered the most irrelevant ode in Greek tragedy»; Marshall, 2014: 115-116), others have tried to show that it is related somehow to the rest of the play (cf. Pippin, 1960: 156; Podlecki, 1970: 411-412; Hanson, 1973: 20; Robinson, 1979).

${ }^{51}$ This mother figure has also been identified with Rhea, Cybele (cf. Pippin, 1960: 162 n. 8; Dale, 1967: 147 n. on 1301-68; Fletcher, 2017: 493, who argues that this ode «features the most extensive example of Euripidean syncretism») or with Nemesis, Helen's mother (Golann, 1945), a view which is generally refuted (cf. Pippin, 1960: 162 n. 8; Hanson, 1973: 23 n. 30).

${ }_{52}$ The two stories also share common features. Like Persephone, Helen was gathering flowers when Hermes snatched her away to a distant land (244-249), Egypt functioning as a sort of 'Hades' for her. Furthermore Helen was worshipped as a vegetation divinity in Sparta, her story being one of death and resurrection, like that of Persephone (cf. Segal, 1971: 581). The Demeter-Persephone theme also foreshadows the positive outcome of Helen's story (Pippin, 1960: 156; Allan, 2008: 305-306 n. on 1349). The relation between the two stories is established already in the first strophe of the parodos where Helen invites Persephone to receive in the underworld her dirges for the dead (175-178); in fact Segal (1971: 595) regards this stasimon as the 'mirror-image' of the parodos as it «resumes and completes the motif of Persephone there stated». For other thematic similarities between the two stories, see Pippin, 1960: 156; Podlecki, 1970: 411-412; Hanson, 1973: 20; Robinson, 1979; Foley, 2001: 306-307; Burian, 2007: 270; Fletcher, 2017: 494.

${ }^{53}$ Cf. Galeotti, 1987: 29.

${ }^{54} \mathrm{Cf}$. also the messenger's suggestion that one should rely on right thought and prudence,

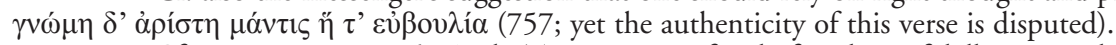

${ }^{55}$ Cf. Hartigan, 1981: 26: «As the Trojan war was fought for a beautiful illusion, so the Sicilian expedition commenced for the attraction of empire». As was conventional for a tragic poet, Euripides exploited the mythical tradition to criticize his contemporary reality, and, like almost all of his later plays, Helen makes a strong denunciation of the evils of war (cf. 365-374, 1151-1157). As Hanson 
Trojan war as the result of both divine ( $\left(1^{\text {st }}\right.$ strophic pair $)$ and human motives $\left(2^{\text {nd }}\right.$ antistrophe) - the gods lured men by sending them an illusion, but they decided to fight for $i^{56}$-indicates the complex interrelation of these two levels. The gods direct mortal action up to a certain extent, yet men can also determine their own fortunes by their choices and attitude to life. They suffer not only because of the deception of the gods but also because of their own decisions and vicissitudes.

The interplay of divine and human action, which is prominent throughout the play, is emphasized especially in Theonoe's decision. Theonoe, an innovation of Euripides, makes an impressive entry, with attendants and purifying torches $(865 \mathrm{ff})^{57}$, which has been prepared from the beginning of the play ${ }^{58}$. Her appearance constitutes the climax of the drama as the salvation of the Greek couple depends on her decisions $^{59}$. Presented as an omniscient prophetess, Theonoe informs Helen that she is aware of Menelaus' arrival and that a debate will take place between Hera and Aphrodite before Zeus to decide his fate (874ff). She explains that Hera favours his return to Sparta together with Helen while Aphrodite is opposed to it ${ }^{60}$, declaring her own position with the controversial phrase $\tau \dot{\varepsilon} \lambda \circ \delta^{\prime} \delta^{\prime} \dot{\varepsilon} \varphi$ ' $\dot{\eta} \mu \tilde{i} v$ (887). The majority view that this phrase means that Theonoe acts as an arbiter between the two goddesses is refuted by Zuntz (1960: 205-206) who argues (205) that it «looks forward, not backward", referring not to the impending divine council but to Theonoe's dilemma whether to save Menelaus and Helen or not. Her decision is independent of the decision of the gods, but somehow it coincides with it. In the exodos of the play the Dioscuri assert that Theonoe's decision has been in accordance with the will of the gods (1647-1649) and praise her for her righteous behaviour (1647-1649, 16561657). As elsewhere in Greek tragedy, «the simultaneous enactment of the drama on two levels, the human and the divine» becomes obvious here ${ }^{61}$. We are informed

(1973: 22) suggests, Euripides perhaps produced Helen not to provide escape from the depressing contemporary reality; «rather...the dramatist not only gives his contemporaries his poetic diagnosis of the causes of their misfortunes, but also offers them the hope of a betterment of the fortunes through.... a willingness to honour and respect...piety and justice, and not the misuse of power for selfish, unjust ends".

${ }_{56}$ Cf. Luschnig, 1972: 162.

${ }^{57}$ This purification rite is not to be regarded as just a piece of theatrical display, but indicates Theonoe's concern for the pure (Hanson, 1973: 13).

${ }^{58}$ Cf. Zuntz, 1960: 208; Hanson, 1973: 12-13.

${ }^{59}$ Zuntz, 1960: 204; Hanson, 1973: 13.

${ }^{60}$ A divine contest between Hera and Aphrodite to settle Menelaus' fate has its Homeric precedent in Athena's and Poseidon's opposition about Odysseus' fate. Cf. Zuntz (1960: 211-212), who sees in the rivalry between the two goddesses a symbolism like the one revealed in the antagonism of Aphrodite and Artemis in Hippolytus, as «the faithful Helen of the play is striving to the utmost to fulfil the demands of the divine protectress of marriage, and rejecting that Kypris to whom the other Helen succumbed".

${ }^{61}$ Hanson, 1973: 15. 
nowhere in the play of the outcome of the Olympian council, and it seems that Euripides deliberately leaves it ambiguous so that Theonoe's decision becomes more important. We learn that she has sided with Hera (1005-1006), yet she still prompts Helen and Menelaus to pray to the gods for their safe return (1024-1027), as they do $(1093 \mathrm{ff})^{62}$, which is another indication of the interplay of divine and human action in the drama.

The couple's pleas to Theonoe (894ff) not to reveal Menelaus' presence to Theoclymenus are not just "a mere rhetorical exercise»" ${ }^{63}$. Theonoe has not yet decided whether to reveal or conceal the truth and her dilemma must be taken seriously, since her life depends on her decision. If she helps the Greek couple to escape she will have to face Theoclymenus' anger and her life will be at risk. Her final choice to serve justice disre-garding her own life brings her in complete contrast to the traditional gods, whose actions are prompted by personal motives, and thus indicates more distinctly the frivolity of divine and the seriousness of human motives. Theonoe's innate sense of justice and morality is higher than that of both the Olympian gods and the seers the messenger referred to (744ff), and so her decision is given striking prominence ${ }^{64}$. As Whitman (1974: 53) remarks, «Theonoe is a remarkable creation, quite without parallel among the characters of extant Greek drama». Her act of selfsacrifice is repeated at the end of the play when a noble servant is opposed to Theoclymenus' threat to kill his sister ${ }^{65}$. In the end, divine providence via the epiphany of the Dioscuri saves both Theonoe and the servant, a confirmation that God helps the just and the righteous ${ }^{66}$.

To conclude, the outline of the plot of Helen is based on a divine plan which is not made known to the human characters of the play from the beginning. Due to their limited understanding and the deception of the gods, men cannot realize the real situations they are involved in, and are often led to miscalculations and errors.

${ }^{62}$ For Helen's and Menelaus' appeals to Theonoe, see Zuntz, 1960: 210-211; Hanson, 1973: 15-17; Marshall, 2014: 38-42. At the end Theonoe recognizes the validity of the couple's claims and responds to their appeals (998ff).

${ }^{63}$ Zuntz, 1960: 210. For the influence of contemporary rhetoric in their speeches, see Griffith, 1953: 39-40; Marshall, 2014: 38-42.

${ }^{64}$ As Theonoe asserts, there is a 'temple of Justice' within herself (1002-1003; for this image, cf. Griffith, 1953: 40; Hanson, 1973: 17). Theonoe is associated with some higher spiritual reality above the gods which she calls aether (866) and from which, as may be deduced from the controversial passage in verses 1013-1016, she receives nous, an immortal substance which guides her to the right (cf. Zuntz, 1960: 204, 213; Matthiessen, 1968: 699-701; Segal, 1971: 585). Thus «[s]he stands like a figure of Dike at the apex of the play» (Pippin, 1960: 157).

${ }^{65}$ In proceeding to punish Theonoe Theoclymenus asserts that he acts in the service of justice (1628), but the attendant replies that true justice sides with Theonoe (1633; cf. 1636) before the Dioscuri appear to confirm his opinion. Like the prophetess the attendant favours justice above life itself - no wonder that Euripides chose a noble slave to express this opinion as he did in the case of Menelaus' servant who commented on the nature of God.

${ }^{66}$ Zuntz, 1960: 209-210. For the appearance of the deus ex machina to prevent violence, see Mastronarde, 2010: 186. 
The power of the gods to control mortal things is undoubted, despite the ambiguity and obscurity of their motives, which remain unresolved till the end. As Helen's story indicates, the gods often use mortals as instruments in order to serve their purposes, yet this does not mean that men cannot act as free agents. The play is constantly acted out on two levels, the divine and the human, and its outcome is presented as the result of the interplay of divine and human action. Yet in the end, Dioscuri's intervention in order to save Theonoe and the servant shows the weakness of mortals to achieve their salvation without divine help. The achievement of truth and knowledge and the success of their aims finally depend on the gods who reward the righteous. Nevertheless, as the plot of the play indicates, within the limits of their humanity, men can determine their fortunes by using their intelligence and wit, despite the fact that the motives and the nature of the gods remain ambiguous.

\section{BIBLIOGRAPHICAL REFERENCES}

Allan, W. (2008): Euripides: Helen, Cambridge University Press, Cambridge/New York.

ARnotT, W. G. (1973): «Euripides and the Unexpected», $G \& R$ 20: 49-64.

ARNotT, W. G. (1990): «Euripides' Newfangled Helen», Antichthon 24: 1-18.

BlaikLOCK, E. M. (1952): The Male Characters of Euripides: A Study in Realism, New Zealand University Press, Wellington.

Blondell, R. (2013): Helen of Troy: Beauty, Myth, Devastation, Oxford University Press, Oxford.

BoedeKer, D. (2017): «Significant Inconsistencies in Euripides' Helen», in L. K. MCCluRE (ed.), A Companion to Euripides, Wiley - Blackwell, Malden, MA/Oxford, 243-257

Burian, P. (2007): Euripides: Helen, Aris \& Phillips, Oxford.

Burnett, A. P. (1971): Catastrophe Survived: Euripides' Plays of Mixed Reversal, Clarendon Press, Oxford.

Conacher, D. J. (1967): Euripidean Drama: Myth, Theme and Structure, University of Toronto Press, Toronto.

CONACHER, D. J. (1998): Euripides and the Sophists: Some Dramatic Treatments of Philosophical Ideas, Duckworth, London.

Dale, A. M. (1967): Euripides: Helen, Oxford University Press, Oxford.

Dunn, F. M. (1996): Tragedy's End: Closure and Innovation in Euripidean Drama, Oxford University Press, Oxford/New York.

FletCher, J. (2017): «Euripides and Religion», in L. K. MCClure (ed.), A Companion to Euripides, Wiley - Blackwell, Malden, MA/Oxford, 483-499.

Foley, H. P. (2001): Female Acts in Greek Tragedy, Princeton University Press, Princeton/Oxford.

Forehand, W. E. (1979): «Truth and Reality in Euripides' Ion», Ramus 8: 174-187.

GaleotTi Papi, D. (1987): «Victors and Sufferers in Euripides’ Helen», AJPh 108: 27-40.

Golann, C. P. (1945): «The Third Stasimon of Euripides' Helena», TAPhA 76: 31-46.

Griffith, J. G. (1953): «Some Thoughts on the Helena of Euripides», JHS 73: 36-41.

Grube, G. M. A. (1941): The Drama of Euripides, Methuen, London. 
Hamilton, R. (1978): «Prologue, Prophecy and Plot in Four Plays of Euripides», AJPh 99: 277-302.

Hanson, J. O. de G. (1973): «Euripides' Helena and Justice», MusAfr 2: 11-23.

Hartigan, K. V. (1981): «Myth and the Helen», Eranos 79: 23-31.

Kannicht, R. (1969): Euripides: Helena (2 vols), C. Winter, Heidelberg.

LatTimore, R. (1958): The Poetry of Greek Tragedy, Johns Hopkins Press, Baltimore.

LusChnig, C. A. E. (1972): «Euripides' Iphigenia Among the Taurians and Helen: Così è, se vi pare!», CW 66: 158-163.

Marshall, C. W. (2014): The Structure and Performance of Euripides' Helen, Cambridge University Press, Cambridge.

Mastronarde, D. J. (2010): The Art of Euripides: Dramatic Technique and Social Context, Cambridge University Press, Cambridge/New York.

MatTHiessen, K. (1968): «Zur Theonoeszene der Euripideischen Helena», Hermes 96: 685-704.

Meltzer, G. S. (2006): Euripides and the Poetics of Nostalgia, Cambridge University Press, Cambridge/ New York.

Nieddu, G. F. (2004): «A Poet at Work: The Parody of Helen in the Thesmophoriazusae», GRBS 44: 331-360.

Pippin, A. N. (1960): «Euripides' Helen: A Comedy of Ideas», CPh 55: 151-163.

Podlecki, A. J. (1970): «The Basic Seriousness of Euripides' Helen», TAPhA 101: 401-418.

RaU, P. (1967): Paratragodia: Untersuchung einer komischen Form des Aristophanes, Beck, München.

Robinson, D. B. (1979): «Helen and Persephone, Sparta and Demeter: The "Demeter Ode" in Euripides' Helen», in G. W. BowersocK - W. BurKerT - M. C. J. Putnam (eds.), Arktouros: Hellenic Studies presented to Bernard M. W. Knox on the Occasion of his 65th Birthday, Walter de Gruyter, Berlin/New York, 162-172.

SEgal, C. (1971): «The Two Worlds of Euripides' Helen», TAPhA 102: 553-614.

Solmsen, F. (1934): «'Ovo $\mu \alpha$ and $\pi \rho \tilde{\alpha} \gamma \mu \alpha$ in Euripides' Helen», CR 48: 119-121.

Wassermann, F. M. (1940): «Divine Violence and Providence in Euripides' Ion», TAPhA 71: 587-604.

WhitMan, C. H. (1974): Euripides and the Full Circle of Myth, Harvard University Press, Cambridge, MA.

WolfF, C. (1973): «On Euripides' Helen», HSCPh 77: 61-84.

Wright, M. (2005): Euripides' Escape-Tragedies: A Study of Helen, Andromeda and Iphigenia among the Taurians, Oxford University Press, Oxford.

Zuntz, G. (1960): «On Euripides' Helena: Theology and Irony», in O. Reverdin (ed.), Entretiens sur l'Antiquité Classique VI: Euripide, Fondation Hardt, Genève, 201-227. 